UDC 316. 663:796.01/09-057

DOI: https://doi.org/10.26661/hst-2019-2-79-08

\title{
FORMATION OF CHARACTER AND IMAGE OF SPORTSMAN AS A COMPETITIVE ADVANTAGE IN MASS MEDIA
}

\author{
CAKRANGLYTE, GINTARE \\ Lithuanian sports university (Kaunas, Lithuania), \\ e-mail: akranglyte.g@gmail.com, ORCID iD: https://orcid.org/0000-0002-0312-4784 \\ Lithuanian Sports University (Kaunas, Lithuania) \\ (C) ANDRIUKAITIENE, REGINA \\ Lithuanian sports university (Kaunas, Lithuania) \\ E-mail: regina.andriukaitiene@1su.lt ORCID iD: https://orcid.org/0000-0002-0691-7333 \\ Lithuanian Sports University (Kaunas, Lithuania) \\ CBILOHUR, VLADA \\ Bogdan Khmelnitsky Melitopol State Pedagogical University (Melitopol, Ukraine) \\ E-mail: bilovlada@mail.ru, ORCID iD: https://orcid.org/0000-0001-6755-7231 \\ Bogdan Khmelnitsky Melitopol State Pedagogical University (Melitopol, Ukraine), \\ Hetmanskaya str., 20, Melitopol, Zaporizhzhia region, 72300
}

\begin{abstract}
As with any large organization, the core value of a professional sports club and its affiliates should be to build and maintain a strong image, which can naturally be the best tool for maintaining a positive reputation for the organization and its members, a well-formed image can be a competitive advantage over other athletes, and that is why there is an increasing focus not only on the image of the organization but also on the image formation of athletes in the media. The research aim - to analyze the image elements and their significance in shaping the image of the athlete in the media. The objectives of the research: to carry out the analysis of the structural elements of athlete's image from the theoretical point of view; to define the role of the media in shaping the image of the athlete; having established the significance of the structural elements of an athlete's image, to define the impact of an attractive athlete's image and the role of the media in the image-building process. Analysis of recent research and publications. The problem of the work is what structural elements make up the image and how it can be used to create an attractive image of the athlete in the media. Cornelissen (2001), Mamedaityte (2003), Druteikiene (2003), Scott (2008), Dulworth (2008), Goffman (2000), Arai et al. (2013), Neves et al. (2015), Arai et al. (2014), Charumbira (2014; 2018), Hasaan et al. (2016) and other authors discuss aspects of organizational and athletic image development, structural elements, image creation management, the impact of a positive image on competitive advantage, maintaining relationships with target groups, the marketing significance of image-building, the role of the media in image-building, and other significant image-forming topics. The following research methods are used for the purpose of the research aim: analysis and synthesis of scientific literature; qualitative research - structured interview, qualitative text analysis. The interview questionnaire is based on the theoretical material of the research and the objectives set. While preparing the research instrument, the first part of the question categories and subcategories are formulated using the model proposed by Arai et al. (2013; 2014) MABI (Model of Athlete Brand Image), which highlights three important aspects in shaping an athlete's image. The second and third question groups are based on the research of Charumbira (2016, 2018), Hasaan et al. (2016), which analyzes the role of the athlete in shaping the image of the athlete, including the media.
\end{abstract}

Formation of character and image of sportsman as a competitive advantage in mass media 
Conclusions. Athlete's image consists of structural elements such as the athlete's experience, which includes competitive style, athletic mastery and behaviour during competitions, attractive appearance, expressed in physical and social attractiveness, style, clothing, body beauty, and demonstrated lifestyle that is characterized by a distinctive life story, relationship endeavors where the athlete is a role model and based on the lifestyle the image and athlete's reputation are formed. While social responsibility and reputation retention play an important role. An attractive image of an athlete may in part result in advertising space, television coverage or increased sponsorship. The media plays a key role in shaping the image of the athlete and is an important tool in the process.

Keywords: athletes, image structural elements, image formation, media.

\section{INTRODUCTION}

Relevance of the work. As with any large organization, the core value of a professional sports club and its affiliates should be to build and maintain a strong image, which can naturally be the best tool for maintaining a positive reputation for the organization and its members. Both the leaders of a sports organization and all members of the organization - athletes - need to understand that having a well-formed image can be a competitive advantage over other athletes, and that is why there is an increasing focus not only on the image of the organization but also on the image formation of athletes in the media. As with any organization, it is important for any athlete to understand and know their prevalent image in society, so that decisions could be made to improve the image when necessary. The problem of the work is what structural elements make up the image and how it can be used to create an attractive image of the athlete in the media. Analysis of publications and research have revealed the root of this problem. Cornelissen (2001), Mamedaityte (2003), Druteikiene (2003), Scott (2008), Dulworth (2008), Goffman (2000), Arai et al. (2013), Neves et al. (2015), Arai et al. (2014), Charumbira
(2014; 2018), Hasaan et al. (2016) and other authors discuss aspects of organizational and athletic image development, structural elements, image creation management, the impact of a positive image on competitive advantage, maintaining relationships with target groups, the marketing significance of imagebuilding, the role of the media in image-building, and other significant image-forming topics. The object of the research: formation of the image of the athlete in the media. The aim of the research: to analyze the image elements and their significance in shaping the image of the athlete in the media. The objectives of the research: to carry out the analysis of the structural elements of athlete's image from the theoretical point of view; to define the role of the media in shaping the image of the athlete; having established the significance of the structural elements of an athlete's image, to define the impact of an attractive athlete's image and the role of the media in the image-building process. The following research methods are used for the purpose of the research aim: analysis and synthesis of scientific literature; qualitative research - structured interview, qualitative text analysis. The object of the research: the 
formation of the image of an athlete in the media. The interview questionnaire is based on the theoretical material of the research and the objectives set. Questions are open-ended because they allow for more detailed, work experience based information. The research instrument is designed to investigate the structural elements of an athlete's image and their significance in image formation, the significance of an athlete's attractive image, and the role of the media in shaping an athlete's image. While preparing the research instrument, the first part of the question categories and subcategories are formulated using the model proposed by Arai et al. $(2013 ; 2014)$ MABI (Model of Athlete Brand Image), which highlights three important aspects in shaping an athlete's image. The second and third question groups are based on the research of Charumbira (2016, 2018), Hasaan et al. (2016), which analyzes the role of the athlete in shaping the image of the athlete, including the media.

The research highlights a comprehensive structure that includes the athlete's image-building components: the media (social media means, media, video games and major sports events), verbal communication (oral, rumors and narratives), impression management, social agents (parents, family members, friends, and community) and team sports (athletic interest, team interest, and team geographical location). In turn, the components of an athlete's image are related to external attributes (behavior, team, achievement, style of play, and skills) and personality describing attributes (physical attractiveness, lifestyle, personal attractiveness, ethnicity and entertainment) and fan loyalty to the athlete.

The research aims to find out how Lithuanian sports journalists define the formation of an athlete's image in the media. In order to deepen the research and obtain the most comprehensive answers, when selecting the respondents, their overall seniority in the media, experience in publishing information on the sports sector, age and education were also elucidated. Table 1 provides information on the informants who participated in the study.

\section{Table 1. Informationon the informants (Source: compiled by the author)}

\begin{tabular}{|l|l|l|l|l|l|}
\hline \multicolumn{1}{|c|}{ Informants } & IN1 & \multicolumn{1}{c|}{ IN2 } & \multicolumn{1}{c|}{ IN3 } & \multicolumn{1}{c|}{ IN4 } & \multicolumn{1}{c|}{ IN5 } \\
\hline Total seniority in the media & 6 years & 7 years & 5years & 5 years & 6 years \\
\hline $\begin{array}{l}\text { Experience publishing } \\
\text { information on the sports sector }\end{array}$ & 6 years & 7 years & 5years & 5 years & 6 years \\
\hline Age & 27 years & 26 years & 28 years & 51 years & 29 years \\
\hline Education & $\begin{array}{l}\text { Higher } \\
\text { university }\end{array}$ & $\begin{array}{l}\text { Higher } \\
\text { university }\end{array}$ & $\begin{array}{l}\text { Masters sports } \\
\text { marketing }\end{array}$ & $\begin{array}{l}\text { Higher } \\
\text { university }\end{array}$ & $\begin{array}{l}\text { Higher } \\
\text { university }\end{array}$ \\
\hline
\end{tabular}

Research ethics. The methods of qualitative research provide the respondents with comprehensive opportunities to express themselves and behave naturally. The researcher followed the principle of voluntary participation in the study, so all individuals were informed that in the

Formation of character and image of sportsman as a competitive advantage in mass media 
event of unacceptable questions they might not answer the questions or terminate the interview at any time. Prior to the interview, the respondents were given general information about the aims and objectives of the research, it was stressed that anonymity was guaranteed, their personal data would not be mentioned in the work, generalized research results would be presented in master's thesis, where respondents' codes IN1, IN2, IN3 IN4, IN5 will be used. The respondents were also informed that having transcribed thetext, the interview soundtrackwould be destroyed.

\section{STRUCTURAL ELEMENTS OF}

ATHLETE'S IMAGE AND THEIR SIGNIFICANCE

We can say that the success of an athlete depends on public opinion about him and his performance. If an athlete manages to create a positive image in the media, it is much easier for him to achieve his goals. Forming public opinion requires effort, some activity known as relations with society or public relations. Public relations is a very broad field of activity, which includes creating and maintaining favorable operating conditions for the organization. Many authors believe that they have the following functions: information, contact (communication), image creation, sales promotion, stabilization. Through public relations, the athlete seeks to convey information to the outside (to the public). Constant exchange of information, i.e., knowledge of facts and opinions is essential for both the athlete and those involved.
Public relations are used to establish and maintain contacts, and to communicate with important areas of society and groups. Close contacts with the media - newspapers, magazines, television, radio - are particularly important. Very important are good contacts with professionally competent specialists, political and economic institutions, recognized authorities, young people.

Although public relations cannot be directly identified with image formation, there is a very close link between them. A positive image existing in society is a good foundation for the success of an athlete. The image represents the athlete and provides information about him to the public. It is important for the athlete to be aware of the importance of the image and to understand that the image does not occur by itself, it requires planned, constant, purposeful activities which are time-consuming, effort-consuming and require material expenditure."Spicy", negative stories that undermine the image can deceive stereotypes and serve as a continuing slam. We can say that hiding information is one of the worst things possible for an athlete's reputation. Doing so may increase distrust of the athlete, and as the information becomes clear, the athlete gets more negative feedback and fans and supporters can turn away from him, so it is important not to withhold information and not to provide false information to the public. Reputation is a very important factor in shaping the image of an athlete in society, and we can identify it as a fundamental 
value for the purposeful image formation.

Reputation can be positive or negative, strongly rooted in the consciousness of stakeholders or not, but there is no athlete who has no reputation among his takeholders. Obviously, no athlete would deny a positive reputation and the approval and support of stakeholders. However, can reputation really be and should be managed? To answer the question of whether an athlete's reputation management is a luxury, a new fashion model, or a necessity dictated by today's conditions, it is necessary to analyze the significance of an athlete's reputation and its potential benefits. Reputation can be defined as one of the most challenging tools for an athlete to implement, requiring great effort and continuity. Reputation is usually created in the society only when the totality of the athlete's image matches reality.

Consequently, there is a reciprocal relationship between the image and the reputation of the athlete. Reputation has a strong impact on the athlete's image. The main factors determining the athlete's reputation can be distinguished as athlete's communication with the public, behavior, clothing, which expresses the athlete's individuality, distinguishability from other athletes. A professional athlete is a unique personality and has the abilit to influence consumers, so building a positive reputation requires the right direction to be taken. Carlson et al (2009) notes that an athlete's qualities such as vigor, sincerity, courage, intelligence, honesty help attract more fans and build a positive reputation. Carlson and Donavan (2013) also emphasize that an athlete who wants to create a positive reputation must be open, imaginative and emotionally stable. Therefore, consumers may be more likely to identify with athletes who are perceived as exceptional and positive characters. Equally important are values such as family, profession, patriotism, spirituality and other values that are valued by society, and they most often enhance an athlete's reputation. By convention, researchers distinguish mind and education as positive values. When an athlete engages in negative activities such as drug use, alcohol abuse, assault, driving offenses, gambling, arrests and other negative activities, it causes consumer dissatisfaction. Similarly, companies that sponsor them, after receiving information, often seek to terminate sponsorship contracts, because that information results in significant financial loss for the athlete sponsoring company. Scientists say that hiding information further aggravates the situation and destroys

athlete-consumer relationships. Sato (2015) observes that an athlete's public apology and acknowledgment of mistakes and seeking to correct them can restore an athlete's positive reputation. So, we can say that it takes a lot of work and effort for an athlete to build a good and favorable reputation, but a good consumer attitude should be the key to a professional athlete that can bring real benefits to his or her personal career.

Identity - defines the totality of human qualities by which we 
distinguish him from others. These are the values, attitudes, ideas that an athlete uses to represent himself. The purpose of the identity is to describe its meaning, purpose and image as a brand. Because social recognition is one of the higher social needs of an individual, the use of events allows potential users to identify themselves with that athlete. Every athlete has some idiosyncrasies. Their totality forms the so-called athlete's identity and their profile expresses their exclusiveness and uniqueness. Profile and identity are interrelated and interdependent. An athlete's identity is a chosen way of showing himself to the environment, reflecting his philosophy, values, attitudes and emphasizing the features he wants to be associated with. The general idea behind creating an athlete's identity is to describe himself or herself as clearly, united and attractive as possible. Therefore, a well-formed athlete's identity can be seen as the basis for developing consumer relationships. By describing his identity and communicating it to different user groups, the athlete creates his or her own image. It is up to the athlete to decide how he or she wants to be presented, for a professional athlete's career ends soon enough. Thus, a distinctive and wellestablished image during a sports career can help shape your personal brand, which can be a great reward for a brief sporting activity. It can also help enter a professional life after a sports career.

Arai et al. $(2013,2014)$ developed the MABI (Model of Athlete Brand Image) model for athlete image assessment and identified theoretical and methodological approaches to fill conceptual gaps in athlete image research. The research results substantiated the main structural elements of the image. The study identifies image dimensions specific for an athlete and person, which are important and commonly used in sports marketing and advertising. Three main components of the MABI model are distinguished: the athlete's experience / game, attractive appearance and demonstrated lifestyle (see Figure 1).

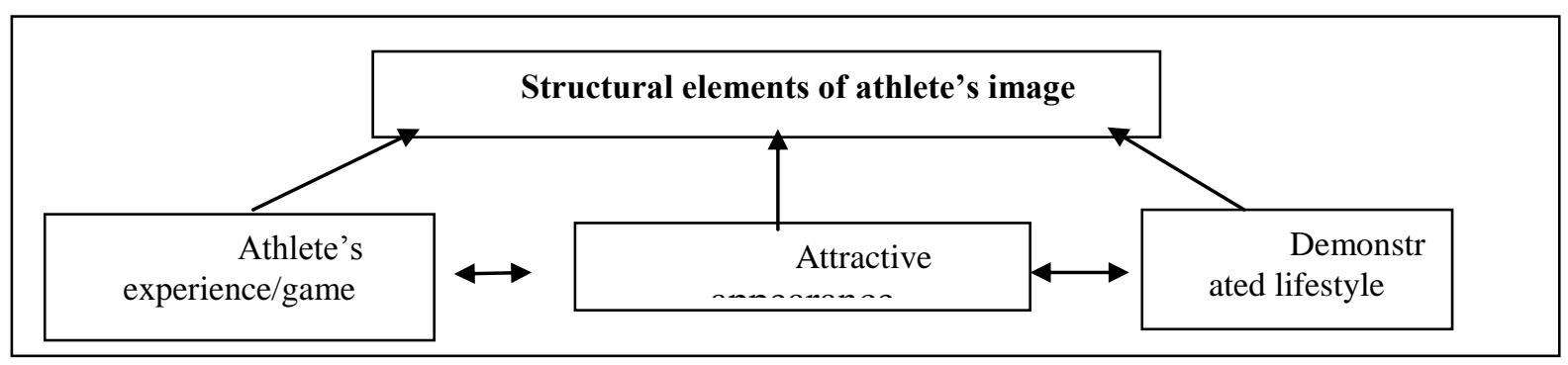

Figure 1. Structural Elements of Athlete's Image (Source: Arai et al., 2013, 2014)

It could be said that the definitions of an athlete's image are highly ambiguous, as scientists view this phenomenon from different angles, highlighting one aspect or another. that a positive image is a very 
powerful force and athletes who are able to manage this force through all the structural elements at the same time gain a competitive advantage, which can often be a great investment in their future. The sports industry is not only one of the most profitable entertainment industries, attracting large investments, but also a business that is subject to constant risk due to potential injuries, withdrawal of key sponsors, staff changes or personal financial failure of shareholders that could impact the team budget. As a result, in anticipation of potential threats, sports organizations adopt annual strategies that in case of bad luck will allow to mitigate potential damage in the event of one of the scenarios listed. However, we can argue that for any professional athlete, as with any organization, the key value should be to create and maintain a strong image in the media, which can naturally be the best means of raising public awareness. The image of an athlete in the media is associated not only with good results and athletic success, but also with the personal qualities of the athlete as an individual. Different sources of information present quite different media concepts. Some view media from a broader perspective, while others present more specific media concepts.

Table 2. Media Concepts (Source: compiled by the author).

\begin{tabular}{|l|l|}
\hline \multicolumn{1}{|c|}{ Source } & \multicolumn{1}{c|}{ The media concept } \\
\hline Habermas (2008) & $\begin{array}{l}\text { The media is a message created by an individual or a group of people and transmitted to a } \\
\text { wide audience by means of information. It includes books, magazines, audio recordings, } \\
\text { newspapers, television, the Internet, movies. }\end{array}$ \\
\hline $\begin{array}{l}\text { Akin, Jennifer } \\
(2005)\end{array}$ & $\begin{array}{l}\text { The media is a variety of information (from hand gestures to international news) } \\
\text { transmitted to a large group of people. There are no rules specifying how large an } \\
\text { audience must be in order for information to become mass. There is also no requirement } \\
\text { for information to be disseminated, so even advertising on the car is classified as media }\end{array}$ \\
\hline Urbonas (2007) & $\begin{array}{l}\text { The media is an individual's area of activity that focuses on the collection, processing and } \\
\text { dissemination of relevant information through a variety of means. "It is an organized } \\
\text { dissemination of information in the system of public information organizers and mass } \\
\text { media; organizers of public information, the media; publications in the press, broadcasts } \\
\text { on radio and television". }\end{array}$ \\
\hline
\end{tabular}

After analyzing and comparing media concepts (see Table 2), it is noticeable that all concepts of media definition are different. Analysis of literature has shown that a unified definition of media is still poorly formulated today. According to the analysis of media definitions, author Habermas (2008) describes the media as a message created by an individual or a group of people that will be communicated to the public through the media. Akin (2005) emphasizes that there are no established norms for the media to specify the size of the audience in order for the information to become mass. It also emphasizes that there is no requirement for information to be disseminated, so even car advertising is classified as media. Urbonas (2007) defines the media as an area of a person's activity that involves collecting, processing, and disseminating relevant information through a variety of means. Arai et al (2013) rank athlete's media appeal in the following sections: athletic mastery, athletic 
achievement, and lifestyle. Researchers emphasize that an athlete's lifestyle includes interaction with fans, athlete's ethical behavior, and declared personal values, which suggests that this is the biggest contribution to shaping an athlete's image in the media. In terms of the media, it is important to emphasize the media groups that Uttara (2008) defines as follows: electronic press, press (newsletters, various newspapers and magazines, brochures, photographs (as visual communication); new media (mobile phones, the Internet and computers). In addition, Kingsley (2004) suggests a more modern media distribution, as the previous distribution does not reveal the latest media trends: broadcasting of programs; movies; video games (games in mobile phones, Arcade games in internet cafes, Console games on selected devices); sound recording and copying (this group includes various sounds and music); press (publishing media); digital Media (satellite connection, mobile phones, the Internet). Mobile phones are the new ubiquitous fashion that is often referred to as the seventh media. The mission of the media is to present current issues to the public, to keep up to date with all the latest developments, and to present different views impartially. Media expands a person's horizons, worldviews, beliefs, knowledge, and behavior. Actively shapes public opinion. It also influences the formation of public values, influences social moods. Uzniene (2009) describes the media as a mirror of events, which, regardless of our wishes, distorts, corrects, filters and selectively selects what we need to know, see, hear. But with its growing influence, the media can easily become more than just a place where cultural and social values are formed and consolidated. Often, popularity is not sought after in the most beautiful ways, and the media expresses not the public opinion, but the opinion of the directors of the television channel or publication. It is very important for the public to have access to information and new knowledge, and the media is one of the most important providers of information. Pitrenaite (2009) states that the media likes unexpected, recent news, rather bad than good news. Most people spend most of their time with one or another source of information: television, the Internet, radio, newspapers, and more. According to Pitrenaite (2009), the media, by analyzing and disseminating information, shapes public awareness of phenomena relevant to the country, directly influencing their values and attitudes.

Consumer communication habits have changed rapidly, leading to the emergence of social media alongside traditional media in today's world. Together, these tools complement each other and create an effective communication system. In today's world, the importance of internet connectivity is extremely high. According to Scott (2008), social life is no longer conceivable without the Internet, which is gradually displacing part of the media as a means of disseminating information. Social connections are moving from the real 
world to a virtual space where life is as active as in the real world. No exception are professional athletes of these days who often rely on social networks such as facebook, twitter or instagram, which facilitate communication with their fans and are a great platform to promote their image.

The media emphasizes its mission to communicate events accurately, to explain current societal problems and to present different views in an unbiased manner. Studies conducted by Balciene and Lebrikaite (2007) showed that $51.3 \%$ of respondents trust the media, $17.4 \%$. - do not trust. Researchers Balciene and Lebrikaite (2007) noticed that lately the media is more inclined to form an attitude than to inform about objective events. The press and web pages (15 min., l.rytas, delfi, etc.) benefit the professional athlete by making him constantly visible. A professional athlete is a prominent person, so no special effort is required to get into the media spotlight. Well-known people are constantly in the spotlight as the most influential and top-tier of society. The lifestyles of professional athletes, their sporting achievements, or events and news related to them, are of constant interest to the public and are therefore constantly communicated to the media. If the media coverage of an athlete's lifestyle or events is positive, it often provokes positive reactions in the public and creates a positive image of the athlete. Conversely, if articles relate to an athlete's bad behavior or lifestyle, they create a negative image of the athlete. Therefore, in order to get good use of the media while forming a positive image, one needs good reputation, good manners and lifestyles.

Social networks are an interactive internet structure (web site) that brings together a group of members with common interests who both create the content for a particular site and interact with each other virtually. Social networks have become an integral part of our lives. Almost everyone now has profiles on various pages, regardless of age, gender, education, income and social status. Social communication has become one of the most effective tools for creating an image. According to author Dulworth (2008), the fundamental aspect that distinguishes social networks from other websites is the ability for individuals to share their relationships with people they do not know. Social networking members join communities and those communities operate not only locally but also globally. This network connects many individuals from around the world, and they themselves process and stream large amounts of information from other participants on the social network themselves. Sociologist Goffman (2000) describes the external features of a person as a term of individual appearance, which can be defined as distinctive signs that help to convey various meanings related to a person (table 3 ).

Table 3. Individual appearance acording to Goffman (Source: Goffman, 2000). 


\begin{tabular}{|l|l|}
\hline & associations that a well-off person dresses in brand clothes, according to their status. \\
\hline Race & $\begin{array}{l}\text { Race represents the origin of a person, and Southerners and Orientals are not just } \\
\text { different in their residence but also in temperament, skin color. }\end{array}$ \\
\hline Sex & $\begin{array}{l}\text { Sex refers to a person's biological origin, where sex distribution prevails and stereotypes } \\
\text { are being created. }\end{array}$ \\
\hline Age & $\begin{array}{l}\text { Age represents not only the biological maturity of a person, but also the accumulated } \\
\text { experience. }\end{array}$ \\
\hline Height & $\begin{array}{l}\text { Height can be categorized as appearance. Height as well as weight have appropriate } \\
\text { associations with a healthy and strong person or with obesity and dwarf. }\end{array}$ \\
\hline Appearance & All external features and clothing of the person represent an attractive person or not. \\
\hline $\begin{array}{l}\text { Facial } \\
\text { expression }\end{array}$ & $\begin{array}{l}\text { Facial features, smile, eyes, gaze facilitate communication, facial expressions help to } \\
\text { understand a speaker's mood. }\end{array}$ \\
\hline $\begin{array}{l}\text { Speaking } \\
\text { models }\end{array}$ & $\begin{array}{l}\text { They are also helpful when communicating, calm, cheerful or rough } \\
\text { speaking reveals a person's moods and manner. }\end{array}$ \\
\hline Body gestures & $\begin{array}{l}\text { Communication provides additional information to the addressee, facilitates } \\
\text { conversation; body gestures can be divided to external stimuli or manners. }\end{array}$ \\
\hline
\end{tabular}

Hasaan et al. (2016) investigated and analyzed athlete's image formation, including the role of the media in shaping an athlete's image. The authors presented a comprehensive structure that incorporates athlete's image-building tools in terms of sources providing information about athletes: the media (social media, media, video games and major sports events); verbal messages (oral, rumors and stories); impression management, social agents (parents, family members, friends and community); team sports (athletic interest, team interest and team geographical location). In turn, the athlete's image components are related to the athlete's external attributes (behavior, team, achievement, playing style and skills) and personality attributes (physical attractiveness, lifestyle, personal attractiveness, ethnicity and entertainment) and fan loyalty to the athlete. As stated by Hasaan et al. (2016), the media is an important tool in the process of creating an athlete's good image and disseminating information about athletes. Scientists have refined the Athlete Image Model (MABI) developed in previous studies and pointed out the need to analyze the opinions of fans that contribute to athlete's image development. Researchers believe that the structural elements of the image must be strategically managed by athletes and trainers themselves. Structural elements of athlete's image and their significance in image formation.

\section{RESULTS AND DISCUSSION}

Interview data were analyzed using the method of qualitative text analysis. For this reason, the text has been read several times and, once the meaning of the text has been understood, the text has been split into separate sections reflecting the essential aspects of the research. The analysis is based on the statements of the respondents. Table 4 lists the distinguished categories and subcategories.

Table 4. Interview categories and sub-categories

\begin{tabular}{|c|c|}
\hline Interview categories & Sub-categories \\
\hline 1. $\quad$ Structural elements of athlete's image and their significance in image formation \\
\hline
\end{tabular}

(C) Akranglyte Gintare, Andriukaitiene Regina, Bilohur, Vlada, 2019 


\begin{tabular}{|c|c|}
\hline Sporting experience & $\begin{array}{l}\text { Significance of sporting experience. } \\
\text { Competitive style (attractive personality, competence, emotion } \\
\text { cause / excitement, team game / game characteristics) } \\
\text { Athletic excellence and professional reliability. } \\
\text { Competitive behavior during competition }\end{array}$ \\
\hline $\begin{array}{l}\text { Attractive appearance: attractive } \\
\text { athlete's outward appearance }\end{array}$ & $\begin{array}{l}\text { Physical and social attractiveness. } \\
\text { Symbol (athlete as personality, social attraction, style, clothing, } \\
\text { design). } \\
\text { Body fitness / body beauty (attractiveness and social } \\
\text { attractiveness). }\end{array}$ \\
\hline $\begin{array}{l}\text { Publicity to lifestyle and personal } \\
\text { qualities }\end{array}$ & $\begin{array}{l}\text { Life story and lifestyle. } \\
\text { Athlete as an example to follow. } \\
\text { Relationship efforts (credibility, social attractiveness, sociability, } \\
\text { social interaction, membership of the organization / loyalty. }\end{array}$ \\
\hline \multicolumn{2}{|c|}{ 2. Significance of athlete's attractive image } \\
\hline Planning an athlete's image & $\begin{array}{l}\text { Planning an athlete's image. } \\
\text { Athlete image formation tools. }\end{array}$ \\
\hline $\begin{array}{l}\text { Significance of the attractive image of } \\
\text { an athlete in the media }\end{array}$ & $\begin{array}{l}\text { Access to television. } \\
\text { Access to the press and social networks. } \\
\text { Increasing advertising volumes. } \\
\text { Attracting viewers. }\end{array}$ \\
\hline $\begin{array}{l}\text { Attractive effect of athlete image on } \\
\text { sponsorship }\end{array}$ & $\begin{array}{l}\text { Opportunities for more sponsorship (business, sports leaders, } \\
\text { politicians, media) }\end{array}$ \\
\hline Significance of an athlete's reputation & The reputation of the athlete as an image shaping factor \\
\hline $\begin{array}{l}\text { Significance of attractive athlete image } \\
\text { to competitiveness }\end{array}$ & Competitiveness as an image shaping factor \\
\hline \multicolumn{2}{|c|}{ 3. The role of the media in shaping the image of the athlete } \\
\hline $\begin{array}{l}\text { The process of shaping the image of an } \\
\text { athlete in the media }\end{array}$ & $\begin{array}{l}\text { Individuals and groups of individuals influencing the formation of } \\
\text { the image of an athlete. The most effective media means. } \\
\text { Criteria for choosing an athlete as an object of information. }\end{array}$ \\
\hline $\begin{array}{l}\text { Ethical factors shaping the image of } \\
\text { athletes in the media }\end{array}$ & $\begin{array}{l}\text { Manipulation and intentional harm in shaping an athlete's image. } \\
\text { The significance of personal acquaintances in shaping the image of } \\
\text { an athlete in the media. } \\
\text { The links between the financial benefit to the journalist and the } \\
\text { content of the information about the athlete. } \\
\text { Unfair competition in shaping the image of athletes / teams. }\end{array}$ \\
\hline
\end{tabular}

\section{Structural elements of athlete's} image and their significance in image formation. The first part of the interview was meant to find out whether the athlete's experience, in particular his athletic achievements, could be identified as a decisive factor in creating a favorable image of the athlete in the media. To achieve this goal, a qualitative category was distinguished - "Athletic experience (competence, success, team success)", which was divided into four subcategories: significance of athletic experience, athlete's competitive style, athletic excellence and professional credibility, competition during matches (Table 5).

Table 5. Sporting experience in image formation

\begin{tabular}{|c|c|}
\hline Sub-category & Proving statement \\
\hline $\begin{array}{l}\text { The significance } \\
\text { of the athletic } \\
\text { experience }\end{array}$ & 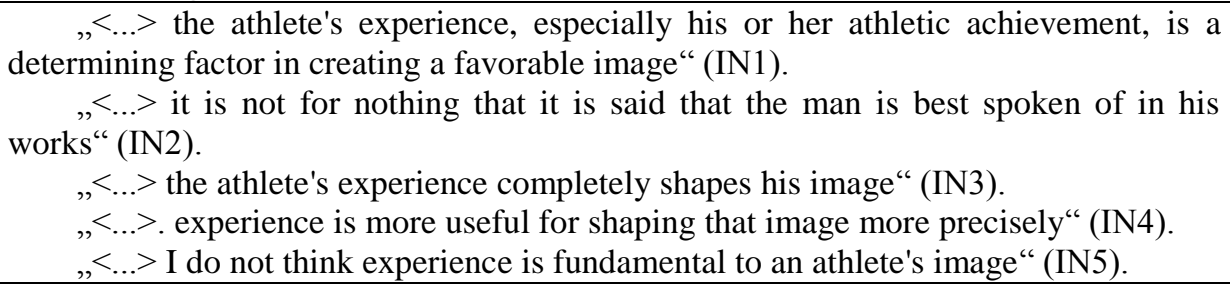 \\
\hline Athlete's & 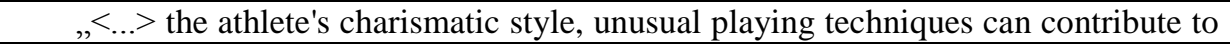 \\
\hline
\end{tabular}

Formation of character and image of sportsman as a competitive advantage in mass media 


\begin{tabular}{|c|c|}
\hline Sub-category & Proving statement \\
\hline competitive style & 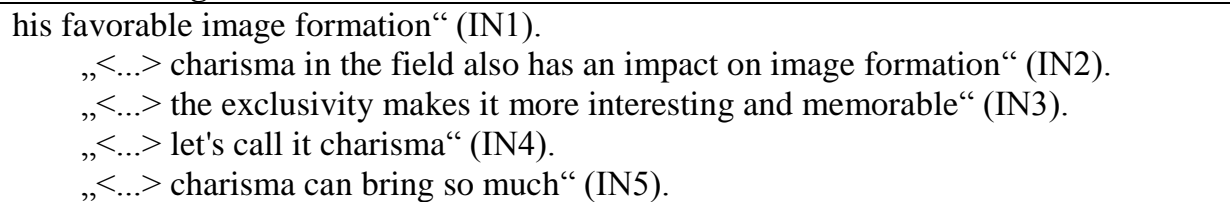 \\
\hline \begin{tabular}{l}
\multicolumn{1}{c}{ Athletic } \\
excellence and \\
professional \\
reliability
\end{tabular} & 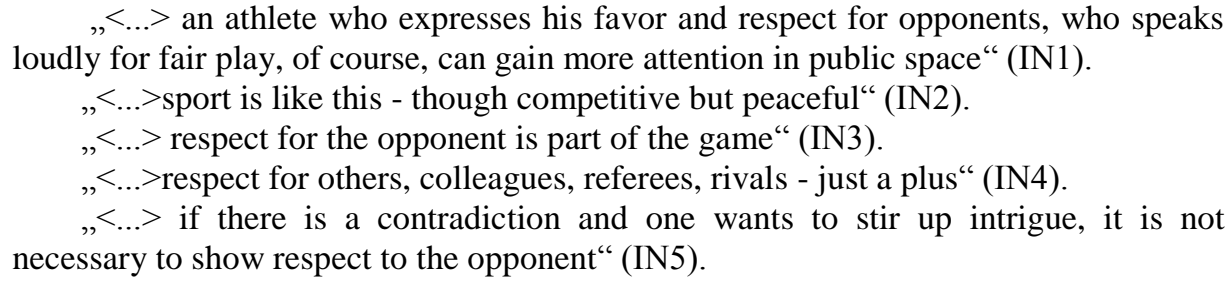 \\
\hline $\begin{array}{l}\text { Competitive } \\
\text { behavior during } \\
\text { competition }\end{array}$ & $\begin{array}{l},<\ldots>\text { exciting, persistent matches to the last seconds help make success stories } \\
\text { about athletes much easier " (IN1). } \\
,, \ldots \ldots \text { in such matches it is important to show yourself from the very best" (IN2). } \\
,, \ldots \ldots \text { it is easier to see the character and qualities of a player in a stressful } \\
\text { situation" (IN3). } \\
,,<\ldots>\text { a spectacle with intrigue is always of interest" (IN4). } \\
,,<\ldots>\text {. if the match is important and challenging and the athlete succeeds, it } \\
\text { contributes significantly to his / her image as he / she looks like a real leader who can } \\
\text { handle the pressure" (IN5). }\end{array}$ \\
\hline
\end{tabular}

Analyzing the significance of athletic experience was meant to clarify journalists' attitudes towards these important elements of the athlete's image and the role of the media in the process. On the first question, "Do you think that an athlete's positive image is shaped by the athlete's experience? If the athletic experience was not emphasized by the media, would it create an attractive image of the athlete in front of fans and other sports market participants?" the respondents emphasized that the experience of an athlete unequivocally shapes the image of an athlete and that it is not for nothing that people are best told by their work. Thus, we can argue that without emphasizing the athlete's experience in the media, it is more difficult to create a positive image of the athlete. In this case, we can argue that unless the athlete's achievements are known, it is difficult to discern his level and authority in the sport he represents. This means that athletic image-building without media is inseparable, it is a key part of athlete's image formation, because with the help of the media there are emphasized the latest news, the ongoing career changes and other news related to experience.

Analyzing the sub-category of athlete's competitive style was aimed at finding out what influence the competitive athlete's style has on image formation, such as, for example, how the style of the competition player is different from other players, the athlete is interesting to watch and the athlete's style is charismatic. In this regard, the respondents emphasized that charisma on the field also influences the image formation and exclusivity on the field makes the athlete more interesting and memorable. Thus, we can say that the athlete's charismatic style, unusual playing technique contribute to the formation of the favourable image of 
the athlete. Standing out from athletes in other sports, the athlete attracts more media attention with more publications. Consequently, this also results in a greater amount of information being created about him.

The sub-category of athletic excellence and professional reliability emphasizes athletes' ethical behavior towards their opponents and the importance of fair play. When asked whether it is important for an athlete to show respect to their opponents and other players, to show fair play, and what significance this has on image formation, the interviewees stated that sport, while being competitive, is peaceful. Respondents also emphasized in their answers that an athlete who is openly expressing his favor and respect for opponents, who speaks loudly for fair play, of course, can gain more attention in the public sphere. So we can say that respect is part of the game, but not always does the respect shown by an athlete automatically lead to a positive image of the athlete, this can be called as accepted and unwritten rules of the sport, the observance of which is selfevident.

Competition during matches is expressed by the ability of an athlete to compete actively in the fight against opponents and creating dramatic exciting situations. The research seeks to find out the journalists' opinion about the importance of this kind of play in shaping the athlete's image. Also important is the extent to which it attracts media attention. When asked

Table 6. Athlete's appearance in image formation whether it is important that a match played by an athlete is interesting, that the athlete is in great opposition with his / her main rival and that the match is dramatic and why and how important it is in image formation, the interviewees confirmed that if the match is important and complicated and the athlete succeeds, it strongly contributes to his or her image as he or she looks like a true leader who can handle the pressure. It is also easier for media representatives to see the character and qualities of a player in a stressful situation.

As a result, persistent matches generate greater attention from the audience, so every action taken by an athlete is further emphasized and a successful athlete creates a more positive image in the media. We can also say that exciting and persistent matches, with the final result being decided only in the last few seconds, make it much easier for the media to create success stories about the athlete.

The second part of the interview sought to find out whether an attractive appearance of an athlete could be identified as a decisive factor in creating a favorable image of an athlete in the media. To achieve this goal, a qualitative category was identified, called "Attractive athlete's appearance", which is divided into four sub-categories: importance of appearance, physical and social attractiveness, symbols and body fitness / body beauty. 


\begin{tabular}{|c|c|}
\hline $\begin{array}{l}\text { Importance } \\
\text { of appearance }\end{array}$ & 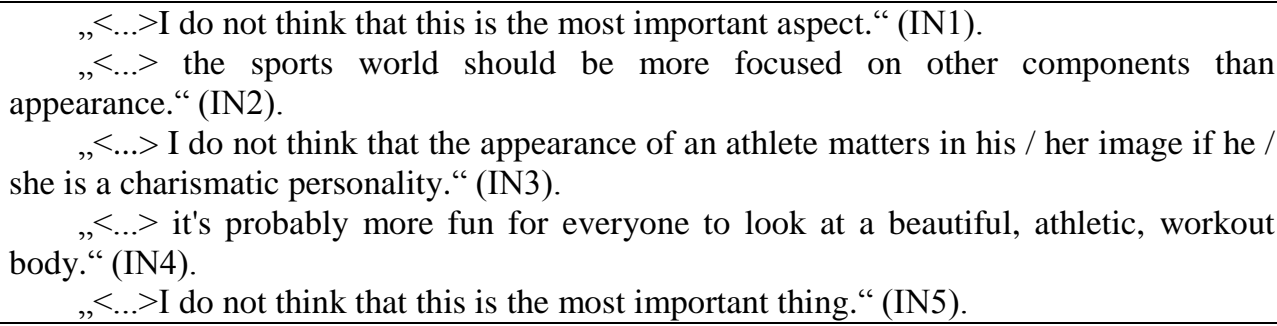 \\
\hline $\begin{array}{l}\text { Physical } \\
\text { and social } \\
\text { attractiveness }\end{array}$ & 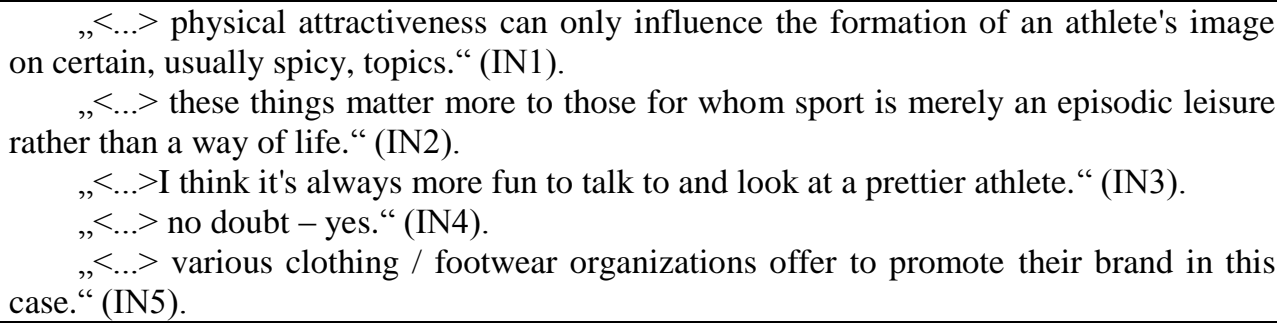 \\
\hline $\begin{array}{l}\text { Symbols } \\
\text { (personality, } \\
\text { social } \\
\text { attractiveness, } \\
\text { style, clothing, } \\
\text { design) }\end{array}$ & 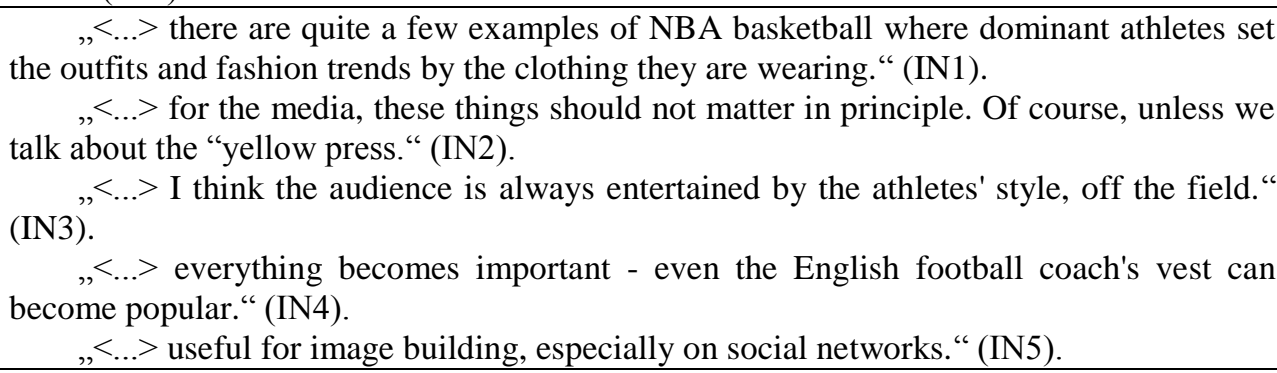 \\
\hline $\begin{array}{l}\text { Body fitness } \\
\text { /beauty } \\
\text { of the body }\end{array}$ & $\begin{array}{l},<\ldots>\text { looking after themselves and strong athletes can attract attention about } \\
\text { themselves." (IN1). } \\
,<\ldots>\text { all athletes are athletic." (IN2). } \\
,<\ldots>\text { a well-shaped athletic body is the business card of athletes." (IN3). } \\
,<\ldots>\text { it is more enjoyable when you talk to attractive-looking interlocutors." (IN4). } \\
,<\ldots>\text { it can lead to the good results that everyone hopes for. I take that into } \\
\text { consideration as well.“" (IN5). }\end{array}$ \\
\hline
\end{tabular}

Analyzing the importance of an attractive athlete's appearance in the athlete's image-building process, media representatives were asked how important an attractive athlete's appearance is to the athlete's image formation. The respondents assured that it is probably more fun to look at a beautiful, athletic, workout body, but that is not the most important aspect. Consequently, it can be argued that an attractive athlete's appearance can form an athlete's image but that is not necessarily associated with his or her image as a great athlete. The physical and social attractiveness subcategory aims to find out if $a$ beautiful, sexy athlete can create a better image. All interviewees confirmed that they had more fun talking to and looking at a more handsome athlete, and emphasized that various clothing / footwear organizations in this case offer the athletes to promote their brand, which not only provides the athlete with an additional source of income but also fame. Consequently, physical attractiveness can only affect the athlete's image formation on certain, mostly "spicy" topics. However, an athlete who does not show good results or good play, even with an attractive physical appearance, will not gain media prominence due to his or her appearance. It can also be argued that the external beauty of an athlete is more important to those for whom sport is merely an episodic pastime rather than a lifestyle. 
Concerning the sub-category of symbols (personality, social attractiveness, style, clothing, design), media representatives had to answer whether an athlete's personal style appeal, style, or modern outfit meeting the up-to-date fashion could create a better image. The interviewees assured that the audience is always interested in the style of the athletes, off-field, but for the media such things should not matter. So, an influential athlete who shows good results can shape fashion and style trends before gaining influence as a great athlete.

Analyzing the importance of body fitness / body beauty in the athlete's image-making process, it was sought to find out whether journalists consider the interlocutor's body beauty in providing information about athletes. The respondents said that all athletes are athletic and it is more enjoyable talking to attractive-looking interlocutors, but this is not the cornerstone that shapes an athlete's image. This means that looking after themselves and strong athletes can attract more media attention about themselves, especially those engaged in professional sports beyond a certain age limit towards the end of their careers.

The third part of the interview sought to find out whether the promotion of lifestyle and personal qualities could be identified as decisive factors in creating a favorable image of the athlete in the media. To achieve this, a qualitative category was identified - "Publicity of Lifestyle and Personal Features", which is divided into three sub-categories: lifestyle and life story, athlete as a model to follow, relationship efforts.

Table 7. Athlete's lifestyle and personal qualities in image formation

\begin{tabular}{|c|c|}
\hline $\begin{array}{l}\text { Sub- } \\
\text { category }\end{array}$ & Proving statement \\
\hline $\begin{array}{l}\text { Lifestyle } \\
\text { and life story }\end{array}$ & 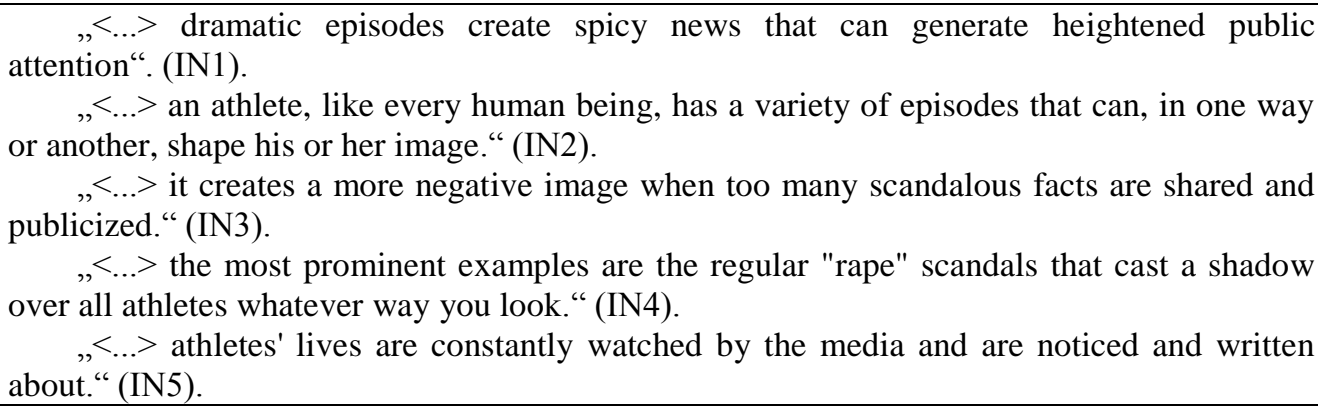 \\
\hline \begin{tabular}{l}
\multicolumn{1}{c}{ Athlete } \\
as an example \\
to follow
\end{tabular} & 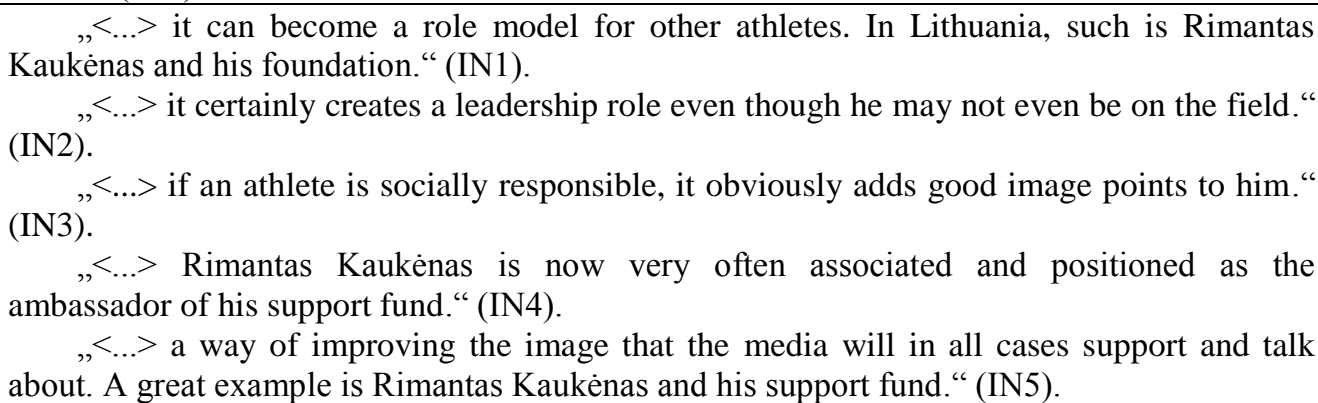 \\
\hline
\end{tabular}

Formation of character and image of sportsman as a competitive advantage in mass media 


\begin{tabular}{|c|c|}
\hline $\begin{array}{l}\text { Relations } \\
\text { hip efforts }\end{array}$ & 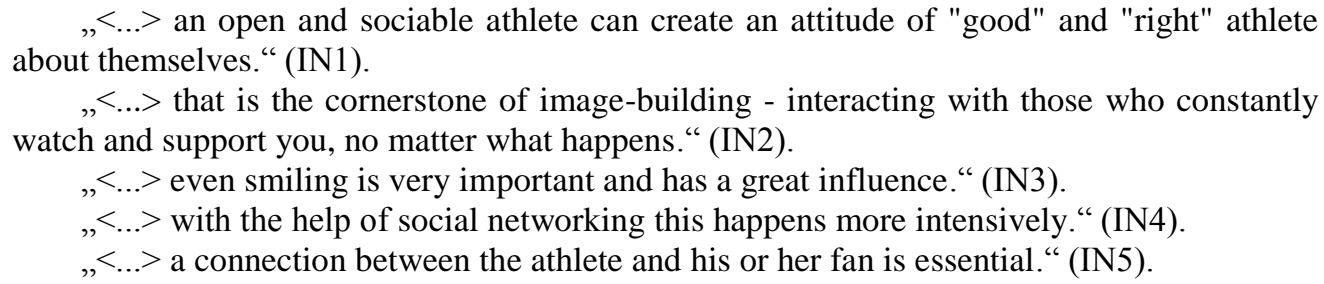 \\
\hline
\end{tabular}

Analyzing the importance of lifestyle and life history in the process of athlete image development, it was sought to determine what importance in athlete's image formation have dramatic episodes existing in personal life and / or exclusive (positive and / or negative) private lifestyles. The respondents stated that an athlete, like every human being, has various episodes that can shape his or her image in one way or another. Dramatic episodes create spicy news that can generate heightened public attention. So, to summarize, dramatic episodes of life, stories are popular with readers as lightweight content news, so the media often uses this in the hope of increasing readers' interest and readability index.

The sub-category of athlete as role model has been explored to determine what importance in athlete's image formation has the fact that the athlete is socially responsible, a good role model, a good leader in the community. In this regard, the respondents identified that a socially responsible athlete can set an example for other athletes. As an example, respondents gave Rimantas Kaukènas and his foundation. This means that being a socially responsible athlete naturally creates a favorable image of a community leader and this does not go unnoticed by the media.
When it comes to athletes' efforts to have good relationship with fans, the question naturally arises what importance in athlete's image formation has the fact that an athlete appreciates his fans and spectators and communicates with them. The respondents speak unanimously on this issue and identify the relationship between the athlete and his or her fans as necessary. So it can be said that communicating with those who constantly watch you and keep you up, no matter what, is required. This means that an open and sociable athlete can create an image of himself as a "good" and "fair" athlete.

\section{CONCLUSIONS}

1. The term of image is not defined in the scientific literature and there is no unambiguous explanation of the concept. Some authors emphasize this term by exploring a person's individual traits, style, clothing and behaviour, while others emphasize the importance of an organization's image. An image is defined as a special image created by the psyche, a set of false or true images, judgments that have been made about an individual, their group, or society as a whole about a particular object. Professional image is not just a set of professional qualities of an individual. There are distinguished such behavioral aspects as individual posture, speaking 
manners and correctness, style of clothing, general culture of a person, which determine the first impression of an individual and create visual information that includes physiological characteristics of an individual.

2. An athlete's image consists of structural elements such as the athlete's experience, which includes competitive style, athletic mastery and behaviour during competitions, attractive appearance, expressed in physical and social attractiveness, style, clothing, body beauty, and demonstrated lifestyle that is characterized by a distinctive life story, relationship endeavors where the athlete is a role model and based on the lifestyle the image and athlete's reputation are formed.

3. An athlete's image consists of structural elements such as the athlete's experience, which includes competitive style, athletic mastery and behaviour during competitions, attractive appearance, expressed in physical and social attractiveness, style, clothing, body beauty, and demonstrated lifestyle that is characterized by a distinctive life story, relationship endeavors where the athlete is a role model and based on the lifestyle the image and athlete's reputation are formed. According to the media representatives, sporting experience and the demonstration of an athlete's lifestyle within each of the sub-categories are significant structural elements in shaping the athlete's image. The structural elements of an athlete's image such as an athletic experience, attractive athlete's appearance, publicity of lifestyle and personal qualities form the necessary whole for shaping an athlete's image, however, the athlete's charismatic style, unusual playing technique, successful performance, exciting and persistent matches, respect for opponents, fans and statement for fair play are all crucial. Dramatic episodes of life attract attention, while social responsibility and reputation retention play an important role. Physical attractiveness can only influence athlete's image formation on certain, mostly "spicy" topics, but an athlete who does not show good results or good play, even with an attractive physical appearance, will not gain media prominence due to his or her appearance. According to the informants, the external beauty of an athlete is more important to those for whom sport is merely an episodic leisure rather than a lifestyle. An attractive image of an athlete may in part result in advertising space, television coverage or increased sponsorship. The media plays a key role in shaping the image of the athlete and is an important tool in the process.

\section{Список использованных источников}

1. Arai, A., Ko, Y. J., \& Kaplanidou, K., 2013. Athlete brand image: Scale development and model test. European Sport Management Quarterly, 13(4), 383-403.

2. Arai, A., Ko, Y. J., \& Ross, R., 2014. Branding athletes: exploration and conceptualization of athlete brand image. Sport Management Review, 17, 97-106. 
3. Akin, J. , 2005. Mass Media [interaktyvus]. Beyond Intractability.org: [žiūrèta $2019 \mathrm{~m}$. kovo 22d.] Prieiga per internetą:< http://beyondintractability.org/essay/mass_communication/>.

4. Balčienè, J., Lebrikaitè, S., 2007. Žiniasklaidos ir visuomenès komunikacijos ypatumai. Lietuvos žiniasklaida jaunujų tyrèjų akimis. Vilnius: VPU leidykla.

5. Carlson, D. B., Donavan, T., 2013. Human Brands in Sport: Athlete Brand Personality and Identification. Journal of Sport Management, 27, 193-206.

6. Carlson, D. B., Donavan, T., Cumiskey, K.J., 2009. Consumer-brand relationships in sport: brand personality and identification. International Journal of Retail \& Distribution Management, 37 (4), 370-384.

7. Charumbira, L. T., 2018. The Integrated Conceptual Framework for Understanding Perceived Brand Equity in Professional Sports Teams. International Journal of Marketing and Business Communication, Vol. 7 (4), p.32-44.

8. Charumbira, L. T., 2014. The effectiveness of the sports marketing strategies used by imbabwean collegiate sports federations. International Journal of Marketing and Business Communication, 3(3/4), 66-75.

9. Cornelissen, J. P., 2001. Integrated Marketing Communications and the language of marketing development. International Journal of Advertising. 20 (4), 483-498.

10. Dulworth, M., 2008. The Connect Effect: Building Strong Personal, Professional, and Virtual Networks. Published by Berrett-Koehler Publishers, 220.

11. Drūteikienè, G. (2003). Organizacijos įvaizdžio ekonominè funkcija // Ekonomika.

12. Goffman, E., 2000. Savęs pateikimas kasdieniniame gyvenime. Knygos The Presentation of Self in Everyday Life (1959) vertimas. Vilnius: VAGA.

13. Habermas, J., 2008. The Structural Transformation of the Public Sphere. Great Britain: Polity Press

14. Hasaan, A, Kerem, K., Rui Biscaia, R., Kwame J. A. Agyemang, 2016. Athlete brand construction: A perspective based on fans' perception. Motriz, Rio Claro, V.22 n.3, 144-159.

15. Kaynak, E., Gulberk Gultekin Salmam, Tatoglu, E., 2008. An integrative framework linking brand associations and brand loyalty in professional sports. Journal of Brand Management, 15(5):336-357. DOI: 10.1057/palgrave.bm.2007.29

16. Kingsley, J., 2004. The Role of the Mass Media in Community Development.

17. James M. Gladden, Richard Wolfe, 2001. Sponsorship of Intercollegiate Athletics: The Importance of Image Matching. International Journal of Sports Marketing and Sponsorship, Vol. 3 (1), pp.29-53, https://doi.org/10.1108/IJSMS-03-01-2001-B005.

18. Mamedaitytè, S., 2003. Ryšiai su visuomene. Autorizuota medžiaga kursams. Vilnius: Lietuvos Teisès Universitetas.

19. Neves, A., Vieira, R., Mourao, F., Rocha, L., 2015. Quantifying complementarity among strategies for influencers' detection on Twitter. International Conference On Computational Science, 51, 2435-2444.

20. Pitrènaitè, B., 2009. Lietuvos žiniasklaidos vaidmuo ugdant visuomenès savisaugos kultūrą. Ekonomika ir vadyba: aktualijos ir perspektyvos. 1 (16), 206-216.

21. Sato, S., Jae Ko, Y., Park, C., Tao, W., 2015. Athlete reputational crisis and consumer evaluation. European Sport Management Quarterly, 15 (4), 434-453.

22. Scott D. M., 2008. Naujosios rinkos ir viešujų ryšių taisyklès. Verslo žinios.

23. Urbonas, V., 2007. Žurnalistikos pagrindai. Klaipėda: Klaipėdos universiteto leidykla.

24. Uttara, M., 2008. Different Types of Mass Media.

25. Uznienè, R., 2009. Medijinis ugdymas: švietimas, lavinimas ir ugdymas apie žiniasklaida: mokomoji knyga. Klaipėda: Klaipėdos universiteto leidykla.

\section{REFERENCES}

1. Arai, A., Ko, Y. J., \& Kaplanidou, K., 2013. Athlete brand image: Scale development (C) Akranglyte Gintare, Andriukaitiene Regina, Bilohur, Vlada, 2019 
and model test. European Sport Management Quarterly, 13(4), 383-403.

2. Arai, A., Ko, Y. J., \& Ross, R., 2014, Branding athletes: exploration and conceptualization of athlete brand image. Sport Management Review, 17, 97-106.

3. Akin, J., 2005. Mass Media [interaktyvus]. Beyond Intractability.org: [žiūrèta $2019 \mathrm{~m}$. kovo 22d.] Prieiga per internetą: $<$ http://beyondintractability.org/essay/mass_communication/>.

4. Balčienè, J., Lebrikaitè, S., 2007. Žiniasklaidos ir visuomenès komunikacijos ypatumai. Lietuvos žiniasklaida jaunųjų tyrèjų akimis. Vilnius: VPU leidykla.

5. Carlson, D. B., Donavan, T. (2013). Human Brands in Sport: Athlete Brand Personality and Identification. Journal of Sport Management, 27, 193-206.

6. Carlson, D. B., Donavan, T., Cumiskey, K.J., 2009. Consumer-brand relationships in sport: brand personality and identification. International Journal of Retail \& Distribution Management, 37 (4), 370-384.

7. Charumbira, L. T., 2018. The Integrated Conceptual Framework for Understanding Perceived Brand Equity in Professional Sports Teams. International Journal of Marketing and Business Communication, Vol. 7 (4), p.32-44.

8. Charumbira, L. T., 2014. The effectiveness of the sports marketing strategies used by imbabwean collegiate sports federations. International Journal of Marketing and Business Communication, 3(3/4), 66-75.

9. Cornelissen, J. P., 2001. Integrated Marketing Communications and the language of marketing development. International Journal of Advertising. 20 (4), 483-498.

10. Dulworth, M., 2008. The Connect Effect: Building Strong Personal, Professional, and Virtual Networks. Published by Berrett-Koehler Publishers, 220.

11. Drūteikienè, G., 2003. Organizacijos įvaizdžio ekonominè funkcija. Ekonomika.

12. Goffman, E., 2000. Savęs pateikimas kasdieniniame gyvenime. Knygos The Presentation of Self in Everyday Life (1959) vertimas. Vilnius: VAGA.

13. Habermas, J. , 2008. The Structural Transformation of the Public Sphere. Great Britain: Polity Press

14. Hasaan, A, Kerem, K., Rui Biscaia, R., Kwame J. A. Agyemang, 2016. Athlete brand construction: A perspective based on fans' perception. Motriz, Rio Claro, V.22 n.3, p. 144159.

15. Kaynak, E., Gulberk Gultekin Salmam, Tatoglu, E., 2008. An integrative framework linking brand associations and brand loyalty in professional sports. Journal of Brand Management, 15(5):336-357. DOI: 10.1057/palgrave.bm.2007.29

16. Kingsley,J., 2004. The Role of the Mass Media in Community Development.

17. James M. Gladden, Richard Wolfe, 2001. Sponsorship of Intercollegiate Athletics: The Importance of Image Matching. International Journal of Sports Marketing and Sponsorship, Vol. 3 (1), pp.29-53, https://doi.org/10.1108/IJSMS-03-01-2001-B005.

18. Mamedaitytè, S. , 2003. Ryšiai su visuomene. Autorizuota medžiaga kursams. Vilnius: Lietuvos Teisès Universitetas.

19. Neves, A., Vieira, R., Mourao, F., Rocha, L., 2015. Quantifying complementarity among strategies for influencers' detection on Twitter. International Conference On Computational Science, 51, 2435-2444.

20. Pitrènaitè, B., 2009 Lietuvos žiniasklaidos vaidmuo ugdant visuomenès savisaugos kultūrą. Ekonomika ir vadyba: aktualijos ir perspektyvos. 1 (16),p. 206-216.

21. Sato, S., Jae Ko, Y., Park, C., Tao, W., 2015. Athlete reputational crisis and consumer evaluation. European Sport Management Quarterly, 15 (4), 434-453.

22. Scott D. M., 2008. Naujosios rinkos ir viešujų ryšių taisyklès. Verslo žinios.

23. Urbonas, V., 2007. Žurnalistikos pagrindai. Klaipéda: Klaipédos universiteto leidykla.

24. Uttara, M., 2008. Different Types of Mass Media.

25. Uznienè, R., 2009. Medijinis ugdymas: švietimas, lavinimas ir ugdymas apie žiniasklaidą: mokomoji knyga. Klaipėda: Klaipèdos universiteto leidykla.

Formation of character and image of sportsman as a competitive advantage in mass media 
АКРАНГЛИТЕ, ГИНТАРЕ - магистр кафедры менеджмента спорта и туризма

Литовский университет спорта (Каунас, Литва)

E-mail: akranglyte.g@gmail.com, ORCID iD: https://orcid.org/0000-0002-0312-4784

АНДРЮКАЙТЕНЕ, РЕГИНА - доктор, лектор кафедры менеджмента спорта и туризма (Каунас, Литва), Литовский університет спорта (Каунас, Литва)

E-mail: regina.andriukaitiene@1su.lt, ORCID iD: https://orcid.org/0000-0002-0691-733

БИЛОГУР, В. Е. - доктор философских наук, профессор, заведующая кафедрой теории и методики физического воспитания и спортивных дисциплин,

Мелитопольский государственный педагогический университет имени Богдана Хмельницкого (Мелитополь, Украина)

E-mail: bilovlada@mail.ru, ORCID iD: https://orcid.org/0000-0001-6755-7231

\section{ФОРМИРОВАНИЕ ОБРАЗА И ИМИДЖА СПОРТСМЕНА КАК КОНКУРЕНТНОГО ПРЕИМУЩЕСТВА В СРЕДСТВАХ МАССОВОЙ ИНФОРМАЦИИ}

Аннотация. Как и в любой крупной организации, основной ценностью профессионального спортивного клуба и его филиалов должно быть поддержка формирование сильного имиджа, что, естественно, может быть лучшим инструментом для поддержания положительной репутации организации и ее членов. Хорошо сформированный имидж может быть конкурентным преимуществом перед другими спортсменами, и поэтому все большее внимание уделяется не только имиджу организации, но и формированию имиджа спортсменов в средствах массовой информации. Цель исследования - проанализировать элементы имиджа и их значение в формировании образа спортсмена в средствах массовой информации. Задачи исследования: анализировать структурные элементы имиджа спортсмена с теоретической точки зрения; определить роль средств массовой информации в формировании имиджа спортсмена; установив значимость структурных элементов, определить роль средств массовой информации в процессе формирования имиджа спортсмена. Анализ последних исследований и публикаций. Проблема иссседования заключается в определении, какие структурные элементы составляют имидж и как их можно использовать для создания привлекательного образа спортсмена в средствах массовой информации. Cornelissen (2001), Mamedaityte (2003), Druteikiene (2003), Scott (2008), Dulworth (2008), Goffman (2000), Arai et al. (2013), Neves et al. (2015), Arai et al. (2014), Charumbira (2014; 2018), Hasaan et al. (2016) и другие авторы обсуждают аспекты развития организационного и спортивного имиджа, структурные элементы, управление созданием имиджа, влияние позитивного имиджа на конкурентное преимущество, поддержание отношений с целевыми группами, маркетинговую значимость построения имиджа, роль средств массовой информации в формировании имиджа и другие важные темы. Для достижения целей исследования используются следующие методы: анализ и обобщение научной литературы; качественное исследование - структунное интервью, качественный анализ текста. Анкета для интервью основана на теоретическом материале исследования. При подготовке инструмента исследования первая группа вопросов сформулированна на основе модели Арай и др. (2013; 2014) (МАВI - модель имиджа спортсмена), в которой выделенны три важных аспекта формирования имиджа. Вторая и третья группы вопросов основаны на исследованиях Charumbira (2016, 2018), Hasaan et al. (2016), в которых анализируется роль спортсмена в формировании имиджа спортсмена, включая и роль средств массовой информации.

(C) Akranglyte Gintare, Andriukaitiene Regina, Bilohur, Vlada, 2019 
Выводы. Образ спортсмена состоит из таких структурных элементов, как опыт спортсмена (соревновательный стиль, спортивное мастерство и поведение во время соревнований), привлекательный внешний вид, выраженный физической и социальной привлекательностью, стиль одежды, красота тела и продемонстрированный образ жизни, который характеризуется своеобразной историей жизни, отношениями, в которых спортсмен является образцом для подражания. На основе образа жизни формируются образ и репутация спортсмена. При этом социальная ответственность и сохранение репутации играют важную роль. Привлекательный образ спортсмена влияет на возможность получить больше времени для рекламы, телевизионному освещению или увеличению спонсорской поддержки. Средства массовой информации играют ключевую роль в формировании имиджа спортсмена и являются важным инструментом в этом процессе.

Ключевые слова: спортсмен, структурные элементы имиджа, формирование имиджа, медиа.

АКРАНГЛІТЕ, ГІНТАРЕ - магістр кафедри менеджменту спорту і туризму, Литовський університет спорту (Каунас, Литва)

E-mail: akranglyte.g@gmail.com, ORCID iD: https://orcid.org/ 0000-0002-0312-4784

АНДРЮКАЙТЕНЕ, РЕГИНА - доктор, лектор кафедры менеджмента спорта и туризма, Литовский університет спорта (Каунас, Литва), эл. п, regina.andriukaitiene@1su.lt, ORCID iD: https://orcid.org/0000-0002-0691-733

БІЛОГУР, В. С. - доктор філософських наук, професор, завідувач кафедри теорії і методики фізичного виховання та спортивних дисциплін, Мелітопольський державний педагогічний університет імені Богдана Хмельницького (Мелітополь, Запорізька область, Україна)

E-mail: bilovlada@mail.ru, ORCID iD: https://orcid.org/0000-0001-6755-7231

\section{ФОРМУВАННЯ ОБРАЗУ ТА ІМІДЖУ СПОРТСМЕНА ЯК КОНКУРЕНТНОЇ ПЕРЕВАГИ У ЗАСОБАХ МАСОВОЇ ІНФОРМАЦІї}

Анотація. Як і в будь-якої великої організації, основною цінністю професійного спортивного клубу та його філій повинна бути підтримка формування сильного іміджу, що, природно, може бути кращим інструментом для підтримки позитивної репутації організації та її членів. Добре сформований імідж може бути конкурентною перевагою перед іншими спортсменами, і тому все більша увага приділяється не тільки іміджу організації, а й формуванню іміджу спортсменів у засобах масової інформації. Мета дослідження - проаналізувати елементи іміджу та їх значення у формуванні образу спортсмена у засобах масової інформації. Завдання дослідження: проаналізувати структурні елементи іміджу спортсмена 3 теоретичної точки зору; визначити роль засобів масової інформації у формуванні іміджу спортсмена, встановивши значущість структурних елементів, визначити роль засобів масової інформації в процесі формування іміджу спортсмена. Аналіз останніх досліджень і публікацій. Проблема іссседованія полягає у визначенні, які структурні елементи складають імідж і як їх можна використовувати для створення привабливого образу спортсмена в засобах масової інформації. Cornelissen (2001), Mamedaityte (2003), Druteikiene (2003), Scott (2008), Dulworth (2008), Goffman (2000), Arai et al. (2013), Neves et al. (2015), Arai et al. (2014 року), Charumbira $(2014 ; 2018)$, Hasaan et al. (2016) та інші автори обговорюють

Formation of character and image of sportsman as a competitive advantage in mass media 
аспекти розвитку організаційного та спортивного іміджу, структурні елементи, управління створенням іміджу, вплив позитивного іміджу на конкурентну перевагу, підтримання відносин з цільовими групами, маркетингову значимість побудови іміджу, роль засобів масової інформації у формуванні іміджу та інші важливі теми. Для досягнення цілей дослідження використовуються наступні методи: аналіз i узагальнення наукової літератури; якісне дослідження - структунное інтерв'ю, якісний аналіз тексту. Анкета для інтерв'ю заснована на теоретичному матеріалі дослідження. При підготовці інструменту дослідження перша група питань сформульована на основі моделі Арай та ін. (2013; 2014) (МАВІ - модель іміджу спортсмена), в якій виділено три важливих аспекти формування іміджу. Друга і третя групи питань засновані на дослідженнях Charumbira $(2016,2018)$, Hasaan et al. (2016), в яких аналізується роль спортсмена у формуванні іміджу спортсмена, включаючи і роль засобів масової інформації.

Висновки. Образ спортсмена складається з таких структурних елементів, як досвід спортсмена (змагальний стиль, спортивна майстерність і поведінка під час змагань), привабливий зовнішній вигляд, виражений фізичною і соціальною привабливістю, стиль одягу, краса тіла і продемонстрований спосіб життя, який характеризується своєрідною історією життя, відносинами, в яких спортсмен є зразком для наслідування. На основі способу життя формуються образ і репутація спортсмена. При цьому соціальна відповідальність і збереження репутації відіграють важливу роль. Привабливий образ спортсмена впливає на можливість отримати більше часу для реклами, телевізійного висвітлення або збільшення спонсорської підтримки. Засоби масової інформації відіграють ключову роль у формуванні іміджу спортсмена і $\epsilon$ важливим інструментом в цьому процесі.

Ключові слова: спортсмен, структурні елементи іміджу, формування іміджу, медіа.

Received date 22.01.2020

Accepted date 02.02.2020

Published date 07.02.2020

(C) Akranglyte Gintare, Andriukaitiene Regina, Bilohur, Vlada, 2019 